\title{
Where are we now and where are we heading in muscle invasive bladder cancer
}

Recently, remarkable developments have been seen in bladder cancer research and treatment. We have seen some amazing advances in genomics and molecular biology that apply precision medicine strategies for diagnosis and treatment of bladder cancer using molecular classification. Further, the treatment landscape of bladder cancer has shifted dramatically over a short period of time and is on going with immune check point inhibitor, antibody drug conjugation, and fibroblast growth factor receptor (FGFR) inhibitor in bladder cancer. These valuable studies require quality reviews.

I am honored to be invited to be the editor of the special edition of Muscle Invasive Bladder Cancer in the Journal of Translational Andrology and Urology, which will contain the latest developments and perspectives to promote the basic understanding of muscle invasive bladder cancer and improve treatment by clinicians, including urologists, based on recent advances in basic science, surgery, bladder-sparing protocol for multidisciplinary approach, variant histology, imaging, and immuno-oncology.

Muscle invasive bladder cancer is associated with high morbidity and mortality. We need more aggressive treatment, including a multidisciplinary approach. Our common goal is to provide optimal treatment to patients; however, the numerous recent developments in muscle invasive bladder cancer may make the treatment choice difficult. Therefore, we have compiled a list of professional authors in each field. We hope to encourage the acquisition of new knowledge and insights on the most relevant topics in muscle invasive bladder cancer. The authors believe that this special edition of muscle invasive bladder cancer will have significantly advance clinical practice and research over the next few years.

\section{Acknowledgments}

Funding: This study was supported by a Korean National Cancer Center grant (NCC1810866-3).

\section{Footnote}

Provenance and Peer Review: This article was commissioned by the editorial office, Translational Andrology and Urology for the series "Muscle-Invasive Bladder Cancer". The article did not undergo external peer review.

Conflicts of Interest: All authors have completed the ICMJE uniform disclosure form (available at http://dx.doi.org/10.21037/ tau-2019-mibc-13). The series "Muscle-Invasive Bladder Cancer" was commissioned by the editorial office without any funding or sponsorship. JHK, HKS and SHK served as the unpaid Guest Editors of the series. JHK serves as an unpaid editorial board member of Translational Andrology and Urology from Jan 2020 to Dec 2021. The authors have no other conflicts of interest to declare.

Ethical Statement: The authors are accountable for all aspects of the work in ensuring that questions related to the accuracy or integrity of any part of the work are appropriately investigated and resolved.

Open Access Statement: This is an Open Access article distributed in accordance with the Creative Commons AttributionNonCommercial-NoDerivs 4.0 International License (CC BY-NC-ND 4.0), which permits the non-commercial replication and distribution of the article with the strict proviso that no changes or edits are made and the original work is properly cited (including links to both the formal publication through the relevant DOI and the license). See: https://creativecommons.org/ licenses/by-nc-nd/4.0/. 


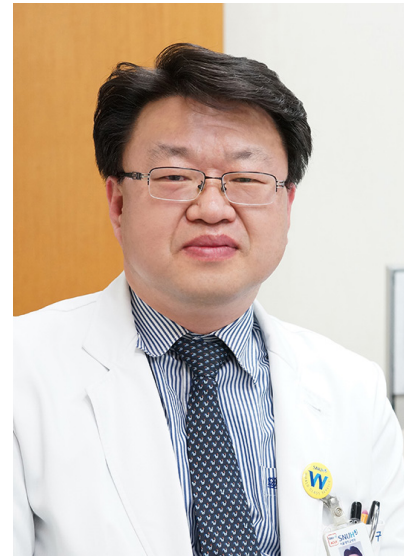

Ja Hyeon $\mathrm{Ku}$

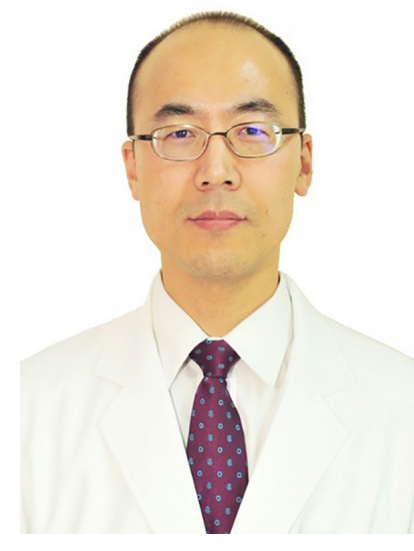

Ho Kyung Seo

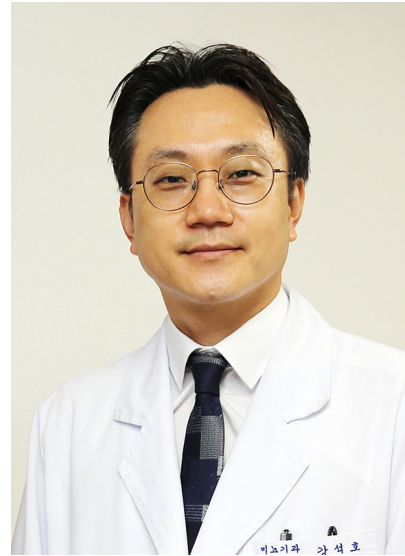

Seok Ho Kang

Ja Hyeon Ku, MD, PhD Department of Urology, Seoul National University Hospital, College of Medicine, Seoul National University, Seoul, Korea.

(Email: kuuro70@snu.ac.kr)

Ho Kyung Seo, MD, PhD

Department of Urology, Center for Urologic Cancer Hospital/Division of Tumor Immunology Research Institute, National Cancer Center, Gyeonggi-do, Korea.

(Email: seobk@ncc.re.kr)

Seok Ho Kang, MD, PhD

Department of Urology, Korea University School of Medicine, Seoul, Korea.

(Email:mdksh@korea.ac.kr)

Submitted Jun 12, 2020. Accepted for publication Jul 31, 2020. doi: $10.21037 /$ tau-2019-mibc-13

View this article at: http://dx.doi.org/10.21037/tau-2019-mibc-13

Cite this article as: $\mathrm{Ku} \mathrm{JH}$, Seo HK, Kang SH. Where are we now and where are we heading in muscle invasive bladder cancer. Transl Androl Urol 2020;9(6):2864-2865. doi: 10.21037/ tau-2019-mibc-13 